April 2011

\title{
A Case Study in Underachievement: The International Courts and Genocide in Bosnia-Herzegovina
}

Marko Attila Hoare

Follow this and additional works at: https://digitalcommons.usf.edu/gsp

\section{Recommended Citation}

Hoare, Marko Attila (2011) "A Case Study in Underachievement: The International Courts and Genocide in Bosnia-Herzegovina," Genocide Studies and Prevention: An International Journal: Vol. 6: Iss. 1: Article 12. Available at: https://digitalcommons.usf.edu/gsp/vol6/iss1/12

This Articles is brought to you for free and open access by the Open Access Journals at Digital Commons @ University of South Florida. It has been accepted for inclusion in Genocide Studies and Prevention: An International Journal by an authorized editor of Digital Commons @ University of South Florida. For more information, please contact digitalcommons@usf.edu. 


\title{
A Case Study in Underachievement: The International Courts and Genocide in Bosnia-Herzegovina
}

\author{
Marko Attila Hoare \\ Faculty of Arts and Social Sciences, Kingston University
}

\begin{abstract}
Two international courts-the UN's International Criminal Tribunal for the former Yugoslavia (ICTY) and the International Court of Justice (ICJ)-have established that genocide occurred in Srebrenica in Bosnia in 1995. Germany's courts have concluded that genocide occurred in both Northern and Eastern Bosnia in 1992, and an appeal against a conviction for genocide on this basis was dismissed by a third international court-the European Court of Human Rights (ECHR). Yet, there has been minimal international punishment of genocide in Bosnia. Serbia was convicted by the ICJ only of a failure to prevent and punish genocide. Only one middle-ranking individual has been convicted of a genociderelated charge by the ICTY; three others of similar or lower rank have been convicted but are appealing the convictions. Only six individuals from Serbia or Montenegro were ever indicted by the ICTY for war crimes in Bosnia and no one has yet been convicted. Of the two most notorious Bosnian Serb genocide suspects-Ratko Mladić and Radovan Karadžic-the first has not yet been arrested while the second was arrested only in July 2008 and has not yet been convicted. International awareness that systematic mass murder occurred in Bosnia and the courts' conclusive verdict that at least some of this involved genocide have translated into minimal punishment of the perpetrators. This paper explores the reasons why international justice has underachieved in regards to the mass murder in Bosnia by examining the structural weaknesses, political pressures, and errors of judgment that have hampered the international courts.
\end{abstract}

Key words: Bosnia, Serbia, genocide, international justice, war crimes

The systematic mass murder that occurred in Bosnia in the first half of the 1990s has perhaps entered into the international consciousness more than any other case of systematic mass murder since the Holocaust. The Bosnian War has been described as the most publicized war in history. Partly as a result of this, the mass murder in Bosnia has received an unprecedented level of attention in the international courts. In 1993, the UN Security Council established the International Criminal Tribunal for the former Yugoslavia (ICTY) to prosecute individual war criminals. The ICTY has indicted over 150 political and military figures from the former Yugoslavia. So far, the ICTY has successfully prosecuted one individual for genocide-the Bosnian Serb officer Radislav Krstić. He was convicted on 2 August 2001, but on 19 April 2004 his conviction was reduced on appeal to the lesser charge of aiding and abetting genocide. A second Bosnian Serb officer, Vidoje Blagojević, was convicted of genocide on 17 January 2005 but subsequently acquitted on appeal on 9 May 2007 of all genocide-related charges. Finally, on 10 June 2010, two more officers, Vujadin

Marko Attila Hoare, "A Case Study in Underachievement: The International Courts and Genocide in Bosnia-Herzegovina," Genocide Studies and Prevention 6, 1 (April 2011): 81-97. (C) 2011 Genocide Studies and Prevention. doi:10.3138/gsp.6.1.81 
Popović and Ljubiša Beara, were convicted of genocide while a third, Drago Nikolić, was convicted of aiding and abetting genocide; all three appealed their convictions on 8 September 2010, and the final outcome remains uncertain at the time of writing.

In the same year that the ICTY was established, Bosnia filed charges with the International Court of Justice (ICJ), accusing Serbia of genocide. The ICJ delivered its verdict in 2007, acquitting Serbia of genocide, but nevertheless finding Serbia guilty of failing to prevent the genocide at Srebrenica and of failing to punish genocide by sheltering war criminals indicted by the ICTY. Also, in 1997, a German court, the Higher Regional Court of Düsseldorf, convicted Nikola Jorgić, a Bosnian Serb, for committing genocide in the Northern Bosnian region of Doboj in 1992. Jorgić challenged his conviction, and brought his case all the way to the European Court of Human Rights (ECHR), to which he appealed on the grounds that the definition of genocide used to convict him in Germany was not in accordance with the international legal definition of the crime. The ECHR rejected his appeal and confirmed the legality of Jorgic's conviction, noting that "the German courts' interpretation has not only been supported by a number of scholars at the relevant time of the commission of the crime" but that "the UN General Assembly agreed with the wider interpretation adopted by the German courts in the present case," and that "[c]onsequently, the applicant's acts, which he committed in the course of the ethnic cleansing in the Doboj region with intent to destroy the group of Muslims as a social unit, could reasonably be regarded as falling within the ambit of the offence of genocide." 1

Thus, three different international courts-the ICTY, the ICJ, and the ECHRhave reached verdicts that support the view that genocide occurred in Bosnia. There is, however, some disagreement between the courts. The ICJ resolved that genocide in Bosnia occurred only in the Srebrenica massacre of 1995. The judges specifically stated that genocide did not occur at other times or places in Bosnia. ${ }^{2}$ The ECHR, by contrast, upheld the decision of the German courts that crimes consistent with the international legal definition of genocide did indeed occur outside of Srebrenicain Northern Bosnia in 1992. Another German court, the Bavarian Appeals Chamber, concluded in the hearing on 23 May 1997 of the appeal of another Serb suspect, Novislav Džajić, that genocide occurred also in the Foča region of East Bosnia in 1992. The ICTY prosecutors tried unsuccessfully to prosecute Bosnian Serb perpetrators for genocide in areas other than Srebrenica. Momčilo Krajišnik, a member of the presidency of Bosnia's Serb Republic-Republika Srpska-was the highest-ranking Bosnian Serb official to be acquitted of genocide. But unlike in the case of the ICJ, the judges at the ICTY did not say genocide had not occurred, but rather that it had not been proven beyond all reasonable doubt. ${ }^{3}$ Ongoing proceedings at the ICTY, in particular against Radovan Karadžić, may yet uphold the prosecution's contention that genocide occurred in Bosnia outside of Srebrenica, though this remains to be seen. Nevertheless, despite these differences, three different international courts agree that genocide occurred in Bosnia or that crimes occurred in Bosnia that can legitimately be defined as genocide.

The paradox is that there has been minimal punishment of this genocide, which has essentially been limited to the punishment of a handful of low- and middleranking individual Serb perpetrators; the highest-ranking suspects thus far convicted of genocide-related charges have been Radislav Krstić, a major-general and deputy commander of the Drina Corps of the Army of the Serb Republic (i.e., the Bosnian Serb army) and Ljubiša Beara, a colonel and Chief of Security of the General Staff of the Army of the Serb Republic. Serbia was convicted of nothing worse than a 
failure to prevent and punish genocide. Bosnia's claim for damages against Serbia was dismissed by the ICJ. Only one individual-a lowly deputy corps commanderhas been convicted of a genocide-related charge by an international court (while Jorgić was a still more lowly figure, a local paramilitary leader, convicted by a national court). Two other low-ranking Serbs, Maksim Sokolović and Đurađ Kušlić, were also convicted of genocide-related offences by German courts. The conviction of Popović and Beara for genocide and of Nikolić for aiding and abetting genocide by the ICTY remains to be upheld or overturned by the appeals chamber.

The War Crimes Chamber of Bosnia-Herzegovina, a hybrid tribunal in which the national judges play the leading role and international judges a supporting role, ${ }^{4}$ has a jurisdiction that is limited to "lower- and intermediate-rank accused," but has been readier to hand down genocide convictions; it found seven low-ranking Serbs guilty of genocide on 29 July 2008, one of whom was subsequently acquitted on appeal. Three other low-ranking Serbs were subsequently convicted of genocide by this court, and a fourth has pleaded guilty to genocide before it. All these cases related to genocide in Srebrenica. Prosecutors at the War Crimes Chamber have not been willing to prosecute suspects for genocide outside of Srebrenica.

Only six people from Serbia or Montenegro were ever even indicted by the ICTY for any kind of war crime in Bosnia. Most of the principal organizers of war crimes in Croatia and Bosnia were never indicted. Of the six indicted, one was killed before being arrested, one died during trial, and procedures against the other four are ongoing. So at the present time, not one single official, soldier, or politician from Serbia has yet been convicted by the ICTY for war crimes in Bosnia, let alone for genocide. Yet it was the regime of Slobodan Milošević in Serbia and the Yugoslav army controlled by Serbia that established the Bosnian Serb army and organized the mass killing in Bosnia-a fact not disputed by the ICJ in its acquittal of Serbia for genocide. Finally, up to the present day, of the two most notorious war-crimes indictees apart from Milošević, namely the Bosnian Serb leaders Ratko Mladić and Radovan Karadžić, the first has still not been arrested while the second was arrested only in July 2008 and has not yet been convicted at the time of writing. So the overwhelming international awareness that systematic mass murder took place in Bosnia and the conclusive verdict of the courts that at least some of this involved genocide have translated into very little in the way of convicting or punishing the perpetrators for the crime of genocide and into relatively little in the way of convicting or punishing the most senior perpetrators even for lesser offences. This paper aims to explore why it is that international justice has failed in the case of Bosnia.

\section{Rejecting Conspiracy Theories}

We can begin by rejecting the easy explanation that international justice failed because the "great powers" wanted it to fail and the international courts are simply the tools of great-power policy. A lot of the discourse about the war in the former Yugoslavia has revolved around theories of Western imperialist conspiracies, and interested parties have posited a number of these conspiracies, most of them supposedly directed against the Serbs. There was, according to various accounts, an imperialist conspiracy to break up Yugoslavia; an imperialist conspiracy to demonize the Serbs by exaggerating their atrocities; an imperialist conspiracy to provoke the war between NATO and Serbia over Kosovo; and so on and so forth. ${ }^{5}$ One of the most imaginative of these supposed conspiracies was the Jewish American conspiracy to appease the Muslim world at the expense of the Serbs to compensate for 
American support for Israel. ${ }^{6}$ On the other side, to a lesser extent, there has been talk of imperialist conspiracies directed against the Muslims. ${ }^{7}$

All conspiracy theories should be rejected in principle because they are not rooted in serious evidence or analysis. This does not mean that serious criticisms should not be made of Western policy. But the most powerful critiques of this kind are made on the basis of empirical evidence. A prime example is Brendan Simms's damning study of British policy toward Bosnia in the first half of the $1990 \mathrm{~s}^{8}$ One of the fiercest critiques of the failure of international justice has been made by Florence Hartmann, the former spokeswoman for Carla del Ponte, chief prosecutor at the ICTY. Hartmann's book Peace and Punishment catalogues many of the failures of the ICTY. ${ }^{9}$ But although there are many things that are positive about Hartmann's book, its principal weakness is that it attempts to portray many of the staff at the ICTY, in particular British and Americans, as motivated by the policies of the Western, in particular British and American, governments which, according to Hartmann, are above all concerned with trying to cover up Western complicity in the Srebrenica massacre and Serbian crimes in general. Having myself worked at the Office of the Prosecutor of the ICTY, I find the idea that most or many staff members were motivated by their governments' policies simply implausible. This applies equally to accusations that the ICTY was "NATO's court," or a political instrument of the great powers. ${ }^{10}$

The ICTY was an institution in its own right, and its actions were determined by its relationship with other institutions and by its own internal structure. There were different bodies and individuals within the ICTY, and there were different currents of opinion. To imply that some of these currents simply reflected the policies of their governments, while others did not, is not credible. This paper will adopt a different approach, and examine the institutional, procedural and conceptual weaknesses and mistakes which have characterised the work of the international courts with regard to Bosnia. We shall begin with the ICTY, because the decisions of the ICTY themselves impacted upon those of the ICJ.

\section{The ICTY's Structural Weaknesses vis-à-vis the Outside World}

The ICTY was structurally flawed in two respects: in its relationship to the outside world and in its internal organization. It was established in 1993 on a shoestring budget, without even the goodwill of most members of the UN Security Council other than the United States. For example, Britain for years failed to donate any money to the ICTY's budget. The ICTY began as an apparently insignificant institution that appeared destined to go after only the small fish. The first person prosecuted was Dušan Tadić, a concentration camp guard who happened to be recognized by one of his former victims in Germany where he was arrested. Although the two most senior Bosnian Serb figures, the political leader Radovan Karadžić and the military leader Ratko Mladić, were both indicted in 1995, the international forces made little or no effort to arrest them in the years immediately following the signing of the peace agreement.

Hartmann argues that the failure to arrest Karadžić and Mladić was deliberate, as these two could have incriminated Western politicians over the events at Srebrenica. ${ }^{11}$ Former ICTY Deputy Chief Prosecutor Graham Blewitt confirmed in an interview following his departure from the Tribunal in 2004 that there was indeed a lack of Western will to arrest the two. ${ }^{12}$ The lack of will was probably related, among other things, to an American fear of possible casualties that might have occurred during an attempt at arrest. Following his arrest in July 2008 and 
delivery to the ICTY, Karadžić attempted to claim immunity from prosecution on the grounds that Richard Holbrooke, the United States's Balkan envoy who brokered the Dayton Peace Accords in 1995, had promised him such immunity on condition that he retire from public life. The ICTY rejected Karadžić's claim to immunity and Holbrooke denied that any such deal had been made. ${ }^{13}$ Nevertheless, US history professor Charles Ingrao has confirmed, on the basis of US State Department sources, that Holbrooke did indeed promise Karadžić immunity from arrest, though not from prosecution, in return for withdrawal from politics. ${ }^{14}$ The ICTY, from the start, therefore suffered from the fact that it had to rely on an unenthusiastic international community to deliver the indictees to it. Furthermore, the ICTY prosecutors had no means of collecting evidence except with the consent of the former Yugoslav states. Both Serbia and, initially, Croatia were essentially hostile to the ICTY, and when they were not forthcoming with the documentary evidence, the ICTY prosecutors had to rely upon the international community to apply the necessary pressure. This, too, was not always forthcoming or sufficient.

In the period after the fall of Milošević in 2000, Chief Prosecutor Carla del Ponte made several trips to Belgrade to seek the cooperation of the new Serbian regime. But this led her into negotiations with Serbian leaders, which arguably resulted in the increasing politicization of the ICTY. Indeed, del Ponte's recently published memoirs reveal that international diplomacy-in the form of negotiations with former-Yugoslav, Western and international officials, in which she was forced to engage in a complex game of threatening and cajoling, demanding and concedingwholly dominated her work as chief prosecutor, at least as she presents it. ${ }^{15}$ This representation of events has been upheld by Victor Peskin's study of the international diplomacy of the ICTY and its sister tribunal, the International Criminal Tribunal for Rwanda. ${ }^{16}$ In order to prove to her Serbian interlocutors that the ICTY was not anti-Serb, del Ponte came under pressure to indict more non-Serbs. We do not know if her policy on indictments was influenced by this pressure. But we do know that of the 125 individuals indicted by the ICTY for war crimes in Bosnia, 89 of them or $71 \%$ were Serb soldiers, politicians, or officials (including at least two non-Serbs who held positions in Serb or Serb-controlled bodies), while 36 or 29\% were Croats and Muslims. ${ }^{17}$ Given that at least $86 \%$ of the killing of civilians during the Bosnian war was the work of Serb forces, this amounts to a substantial overrepresentation of non-Serbs among the indictees-non-Serbs carried out one seventh of the killing of civilians but made up two sevenths of indictees. ${ }^{18}$ Serbia and the Bosnian Serb Republic-Republika Srpska-were the least cooperative with the former Yugoslav entities with regard to the ICTY and this resistance may have paid dividends, with the ICTY prosecutors backing off.

\section{Deficiencies in the ICTY's Internal Organization}

\section{The National Quota}

The ICTY has been caught between Serbian and Bosnian Serb obstructionism on the one hand and inadequate support from the international community on the other. But its failures also stem from its own internal organization. The internal organization of the ICTY's Office of the Prosecutor is not open to the public, but as I worked there myself, I can provide some inside information. Hartmann and del Ponte have also provided some insights in their books, as have Blewitt and Geoffrey Nice (former chief prosecutor in the Milošević trial) in interviews. I was working at the Office of the Prosecutor in 2001, when the ICTY seemed to be at the height of its success. It was in this period that Milošević arrived at the Hague. At that time, the Office of the 
Prosecutor had eleven investigative teams. Of these, seven teams were devoted to Serb war crimes and four to non-Serb war crimes.

As noted above, at least $86 \%$ of the killing of civilians in the Bosnian war was the work of Serb or Serb-controlled forces. There are no comparably precise figures for civilians killed by Serb vis-à-vis non-Serb forces in the Croatian and Kosovo wars. Total Croatian war losses between 1991 and 1995 have been most scientifically estimated at 22,192 ; non-Serbs made up 15,970 , or $72 \%$ of the total; of these, $45 \%$ were civilians, while of the 6,222 Serbs killed or missing, the proportion of civilians is unknown. ${ }^{19}$ Total Kosovo Albanian war losses have been estimated at 10,356 for the period between March and June 1999 according to one scientific study and at 12,000 for the period between February 1998 and June 1999 according to another. ${ }^{20}$ There are no accurate figures to confirm how many of these were civilianssomething especially difficult to calculate, given that "Albanian military casualties" in Kosovo would refer to losses sustained by an irregular, guerrilla army. Nor are there any accurate figures for Serb losses at the hands of the Kosovo Liberation Army. But by any reckoning, Serb forces were responsible for well over $80 \%$ of civilian casualties in all of the former Yugoslav wars combined.

However, at the time that I was working at the ICTY, seven out of the eleven investigative teams (64\%) at the Office of the Prosecutor were devoted to investigating Serb crimes and four (36\%) to investigating Croat, Muslim, and Albanian crimes. This means that Serb indictees were underrepresented in relation to their share of the war crimes-less than two thirds of the investigative teams were devoted to the side in the war that was responsible for over four fifths of total civilian fatalities. Such an organizational structure appears to have been set up in order to guarantee a particular distribution of indictees between the nationalities, as each investigative team would work to achieve a certain number of "kills." Indeed, the distribution of indictments between Serbs and non-Serbs broadly corresponds to the distribution of the investigative teams: of 159 total indictments, 108 or $68 \%$ were of Serbs (i.e., of soldiers, officials, and politicians of Serb or Serb-controlled bodies) and 51 or $32 \%$ were of non-Serbs (i.e., of soldiers, officials, and politicians of Croatia, the Bosnian government, Albanian or Macedonian bodies). The motive may have been to refute accusations of "anti-Serb bias" and to convince the international public that the prosecution was even handed.

There were some peculiarities that arose as a result. The top Yugoslav army commanders, who commanded the Yugoslav and Serb forces against Croatia in 1991-1992, were not indicted. Only middle-ranking officers were indicted for the single worst war crime of the Croatian war, at the Vukovar Hospital, while two other relatively junior officers and two somewhat more senior but not top-ranking ones were indicted over the JNA (Yugoslav People's Army) attack on Dubrovnik. By contrast, the most senior Croatian commander in the period between 1992 and 1995, Chief of Staff Janko Bobetko, was indicted for a crime occurring when Croatia attempted to recapture some territory in 1993 at the Medak Pocket. The top commander of the Croatian Interior Ministry forces, Mladen Markač, was indicted for crimes carried out during Operation Storm in 1995. Overall, more senior Croatian commanders were indicted over Operation Storm than was the case for Yugoslav commanders indicted over the war against Croatia.

Similarly, the top Yugoslav army commanders who commanded Yugoslav and Serb forces during the assault on Bosnia in 1992 were not indicted. Only Momčilo Perisić, the Yugoslav Army commander from 1993 onward, after the direct Serbian aggression had already ended, was indicted. By contrast, the two most senior 
Bosnian Army commanders during the war, Sefer Halilović and Rasim Delić, were both indicted. So in terms of top commanders, Serbia was treated more leniently than either Croatia or Bosnia, in regards to the war crimes committed in those countries. This had nothing to do with lack of evidence. On the basis of the principle of command responsibility, the prosecutors only had to prove that the top Yugoslav commanders had formal command over the lower-ranking officers they had already indicted-such as the Vukovar Three, for example-and they would have had a case. The prosecutors simply chose not to make these indictments.

\section{Overemphasis on Bosnians}

There was, furthermore, an additional distortion, which was that the indictments of both Serbs and Croats disproportionately targeted Bosnian Serbs and Bosnian Croats. Thus, over three quarters of all Serb indictees were Bosnian Serbs, and over three quarters of all Croat indictees were Bosnian Croats. This can be explained in a number of ways. One possibility is that the policy of targeting Bosnians was related to low expectations; that is, the prosecutors avoided targeting Serbs from Serbia because they did not believe they would ever be arrested and so they felt that it would be a waste of time. Hartmann claims that until Milošević actually arrived at the Hague, even senior prosecutors did not believe that he ever would. ${ }^{21}$ This appears possible to me. When I was working at the Tribunal, I remember that staff would discuss among themselves whether Milošević or Karadžić would arrive first; we just did not know. Indeed, when Bosnian Serb Presidency member Biljana Plavšić, one of the most senior figures to be tried, arrived promptly at the Tribunal after being indicted in January 2001, her arrival was something of a surprise and the case against her had not been properly prepared. She was allowed to make a plea bargain for a sentence of only eleven years, she was not required to testify against others, and the genocide charge against her was dropped.

The ICTY began life as a Tribunal that targeted the little fish, and even as it gained strength and confidence, it was not able to change its structural character and behave like a Tribunal that targeted the big fish. Thus, the ICTY has prosecuted numerous camp guards and middle-ranking officers, but has avoided indicting most of the principal organizers of the war in Bosnia. A second explanation is that the members of the Office of the Prosecutor who decided whom to indict did not include any actual experts on the war in the former Yugoslavia. There were academic specialists on the war, such as myself, who were working at the Tribunal, but we were researchers, not decision makers. This is a point that Hartmann stressed to me when we discussed this subject; the lawyers and police personnel who took the key decisions on indictments simply may not have understood the mechanisms of the conflict all that well. ${ }^{22}$ They may really have believed that the conflict was a civil war for which Serbia was not directly responsible.

\section{Failure to Pursue the "Joint Criminal Enterprise"}

We shall return later to the question of whether what happened in Bosnia outside of Srebrenica was genocide or whether it was simply systematic mass murder. Leaving that question temporarily aside, the evidence is nevertheless conclusive that what happened in Bosnia was a centrally planned and directed programme of mass killings that originated with the Milošević regime in Belgrade. All Bosnian Serb forces were both de jure and de facto under the command of the JNA right up until 19 May 1992. The JNA was under the control of the republics of Serbia and Montenegro. Mladić, the Bosnian Serb commander, was appointed to his position by the Yugoslav 
military command. ${ }^{23}$ The largest phase of mass killings occurred during the spring and summer of 1992. This means that it was the regime in Belgrade that was directly responsible for the largest phase of mass killings.

Indeed, the text of the indictment of Miloševic for war crimes in Bosnia claimed that he was part of the Joint Criminal Enterprise, the purpose of which was defined as "the forcible and permanent removal of the majority of non-Serbs, principally Bosnian Muslims and Bosnian Croats, from large areas of the Republic of Bosnia and Herzegovina."24 The Joint Criminal Enterprise included the leaders of Serbia, Montenegro, the Yugoslav army, the Bosnian Serbs, and the Croatian Serb rebels, with Milošević accused of exercising effective control or substantial influence over all of them. ${ }^{25}$ The indictment thus affirmed a central direction and an overall plan to the programme of ethnic cleansing and mass murder. However, the prosecutors did not follow this up. Of the seven other members of the Joint Criminal Enterprise from Serbia and Montenegro who were mentioned in the indictment and were still alive, only three were ever indicted and none of them has yet been convicted.

\section{The Obsession with Milošević}

This brings us to the final reason for the ICTY's failure: the prosecutors' obsession with Milošević as an individual. When I was working at the Tribunal, I was attached to the investigative team (Team 5) that was responsible for drafting the indictment of Milošević for war crimes in Bosnia. My team originally drafted a joint indictment of several members of the Joint Criminal Enterprise, including all the other members from Serbia and Montenegro. However, del Ponte rejected this joint indictment and insisted on indicting only Milošević. At the time, the rumor was that for egotistical reasons she wanted to have something like a personal duel with Milošević, as the most famous indictee, and did not want other indictees complicating the picture. Recently, Hartmann wrote to me to suggest a different reason for Milošević being indicted alone. She argues that the prosecutors wanted rapidly to indict him for Bosnia and for Croatia, as Miloševic had just arrived at the Hague, and the case against other senior figures from Serbia and Montenegro simply was not ready. ${ }^{26}$

Be that as it may, the decision was a mistake. In a recent interview, Nice himself recognized this. The decision meant that the trial came to an end when Miloševic died. Had several indictees been tried together, the trial could have continued without him. ${ }^{27}$ Milošević, as the former president of Serbia and of the Federal Republic of Yugoslavia and as the genuine architect of the war, was certainly an important figure to prosecute. Had he been convicted and sentenced, justice might arguably have been at least partially satisfied. But this overemphasis on the internationally infamous figure of Milošević proved counterproductive when he died before being convicted.

Even if he had survived, the prosecution's excessive focus on Miloševic created enormous problems for its case. From November 2001, the prosecution sought and eventually achieved the merging of Milošević's separate indictments for war crimes in Croatia, Bosnia, and Kosovo into what Gideon Boas has described as "one gargantuan indictment," motivated by del Ponte's expressed belief that such a joinder "would finally make it possible to know the truth as to the real responsibilities of the accused Milošević." 28 Yet as Boas had shown, the prosecution's attempt to have Milošević tried for a very large number of charges over a very wide crime base not only made its case quantitatively difficult to manage, but resulted in confusion at the conceptual level that undermined its effort. ${ }^{29}$ 


\section{Deficiencies in the ICJ}

\section{Restricted Definition of Genocide}

The ICJ was much older than the ICTY and it is a permanent, not an ad hoc, body. Nevertheless, part of the reason why Bosnia lost its case against Serbia has its roots in the political origins of the 1948 UN Convention for the Prevention and Punishment of the Crime of Genocide. Rafael Lemkin, the man who coined the term "genocide" and who was responsible for its insertion into international law, had originally favored a broader definition of genocide to the one that was ultimately adopted. According to the Convention:

Genocide means any of the following acts committed with intent to destroy, in whole or in part, a national, ethnical, racial or religious group, as such:

(a) Killing members of the group;

(b) Causing serious bodily or mental harm to members of the group;

(c) Deliberately inflicting on the group conditions of life calculated to bring about its physical destruction in whole or in part;

(d) Imposing measures intended to prevent births within the group;

(e) Forcibly transferring children of the group to another group. ${ }^{30}$

As Mark Levene has written, Lemkin wanted to include forced exile and population displacement-i.e., ethnic cleansing-and the deliberate destruction of a cultural heritage in the list of genocidal acts, but these were vetoed by some of the UN member states that were involved in the drafting process. ${ }^{31}$ Since Bosnia proved that both ethnic cleansing and systematic cultural destruction had occurred in its case against Serbia, there is no doubt that had Lemkin's original, broader definition of genocide been adopted, Bosnia would have won its case.

\section{The Censoring of the Supreme Defence Council Minutes}

A second political factor that negatively influenced Bosnia's chances was the result of decisions taken by the judges at both the ICTY and the ICJ. Serbia was required to submit to the ICTY judges in the Miloševic case the minutes of the Supreme Defence Council of the Federal Republic of Yugoslavia-the body made up of the presidents of Serbia, Montenegro, and Yugoslavia (i.e., of Milošević and two of his allies). This body initially had command over all Bosnian Serb forces, up until 19 May 1992, and subsequently remained in command of the Yugoslav Army up to and after the time of the Srebrenica massacre, during which time it collaborated with the Bosnian Serb forces. The judges at the ICTY, however, allowed Serbia to withhold certain passages from this set of documents in the version seen by the public and by the ICJ. ${ }^{32}$ Bosnia could not, therefore, use these crucial documents for its case against Serbia. Bosnia requested the ICJ to subpoena Serbia to hand over the uncensored minutes of the Supreme Defence Council, but the judges refused, claiming that there was already sufficient evidence in the public domain. Serbia's unwillingness to allow the uncensored minutes of the Supreme Defence Council to be made public arose precisely out of its fear that they would prejudice its case at the ICJ. Phon van den Biesen, a member of the Bosnian team, has gone on record to say that the full documents would probably have demonstrated that the Bosnian Serb forces were under Serbia's control during the Srebrenica massacre. ${ }^{33}$

Bosnia's case against Serbia was a civil case, meaning that if Bosnia had won, Serbia would have been liable to pay damages to Bosnia. Nevertheless, Bosnia was 
required to prove genocide beyond all reasonable doubt, without having any means of obtaining confidential documents-no subpoena and no police force. So, on the one hand, the ICJ expected the Bosnian legal team to prove beyond all reasonable doubt that Serbia was guilty, as if this were a criminal case, but on the other hand, it refused to make Serbia hand over key items of evidence and forced Bosnia to rely on the evidence it had available to it-a policy that would be more appropriate to a civil case. ${ }^{34}$

\section{Genocidal Intent}

The ICJ judges nevertheless accepted that Serb forces in 1992 were guilty of systematic massive killings and massive mistreatment of the Bosnian Muslims that bore all the characteristics of genocide, except that genocidal intent had not been proven. A pattern of killing across Bosnia was shown but was not considered proof of genocide; ethnic cleansing and cultural destruction were likewise not considered proof of genocide. Still, the Bosnian legal team succeeded in proving to the judges' satisfaction that genocide had occurred at Srebrenica in $1995 .{ }^{35}$ And this peculiarity, that genocide was proven to have occurred in one place and at one time in Bosnia but not in any other place or at any other time, raises to some interesting paradoxes.

The Bosnian Serb armed forces were created by the regime in Belgrade and remained under its formal control up until 19 May 1992. Bosnian Serb commander Mladic was handpicked by Belgrade for the post. Bosnian Serb forces under Belgrade's control were found guilty of systematic mass killings and mistreatment of Bosnian Muslims across Bosnia, but these systematic mass killings nevertheless fell short of genocide in the eyes of the judges. However, after this Bosnian Serb commander and these Bosnian Serb armed forces had become formally independent of Belgrade, they went on to commit genocide at Srebrenica. It is important to recall, at this point, the principle of command responsibility. Since Radislav Krstic was successfully convicted of aiding and abetting genocide, Mladić, as his commanding officer, could straightforwardly have been prosecuted for the same crime-unless he could show that he had taken steps to prevent what Krstic was doing or to punish him afterwards, which he evidently did not. Furthermore, Mladić's direction of the events at Srebrenica was very public and prominent. ${ }^{36}$ So according to the ICJ's reasoning, Mladic acquired a genocidal intent at some point after he gained his independence from Belgrade. His forces continued to be armed and supplied from Belgrade, his officers' salaries continued to be paid by Belgrade, and the regular Yugoslav Army continued to provide his forces with logistical support. But, according to the ICJ, by the time of Srebrenica there was apparently a split between Belgrade, which aimed to carry out the systematic massive killings, torture, rape, and ethnic cleansing of Muslims but without genocidal intent, and Mladić's Bosnian Serbs, who aimed to massacre the Muslims of Srebrenica, with genocidal intent.

The ICJ's conviction of Serbia for failing to prevent genocide rested on its argument that Belgrade should have been aware of the risk that Mladic would not simply carry out massive killings, torture, and ethnic cleansing at Srebrenica, but that he had acquired a genocidal intent. The ICJ did not say that Belgrade should have been aware of this newly acquired genocidal intent on the basis of any documentary evidence or any past behavior. The ICJ said that Belgrade should have been aware of the risk of genocide purely on the basis of the supposed degree of popular hatred on the part of local Serbs toward local Muslims in the region around Srebrenica and on the indications given by Mladic and by international observers that some sort of massacre was going to happen. The judges ruled: 
The Federal Republic of Yugoslavia leadership, and President Milošević above all, were fully aware of the climate of deep-seated hatred which reigned between the Bosnian Serbs and the Muslims in the Srebrenica region. As the Court has noted in paragraph 423 above, it has not been shown that the decision to eliminate physically the whole of the adult male population of the Muslim community of Srebrenica was brought to the attention of the Belgrade authorities. Nevertheless, given all the international concern about what looked likely to happen at Srebrenica, given Milošević's own observations to Mladić, which made it clear that the dangers were known and that these dangers seemed to be of an order that could suggest intent to commit genocide, unless brought under control, it must have been clear that there was a serious risk of genocide at Srebrenica. Yet the Respondent has not shown that it took any initiative to prevent what happened, or any action on its part to avert the atrocities which were committed. ${ }^{37}$

So the judges are saying that it was the hatred that was the root cause of the genocide, and that Belgrade should have been aware of the hatred and of the risk that it might cause genocide at Srebrenica.

This is plainly nonsensical. Even if one were to accept the highly dubious proposition that it was the local Serb hatred of Muslims that gave rise to a genocidal intent, there is absolutely no way of showing that Serbs at Srebrenica hated Muslims more than Bosnian Serbs elsewhere hated Muslims. In other parts of Bosnia, there were mass killings, incredible acts of cruelty and torture, and the mass rape and humiliation of women. There is no reason why such things should be evidence of a lesser degree of hatred than that shown by the Serbs of Srebrenica. If anything, the Srebrenica massacre indicates more cold-bloodedness than some other Bosnian Serb war crimes. Furthermore, the systematic massacre of 8,000 people does not occur spontaneously, but requires a lot of planning and logistical support. It is difficult to see how Mladić, who presided over this process and who was not even from Srebrenica, could have imbibed enough of this local hatred to have been moved to organize such a massacre. And it is doubly difficult to see how Belgrade could have been aware that Mladić's Bosnian Serbs hated the Srebrenica Muslims more than they hated the Muslims they had murdered, tortured, and raped in other parts of Bosnia. This indicates that the ICJ's decision to acquit Serbia of genocide and other genocide-related charges but to find it guilty of failing to prevent genocide at Srebrenica is a form of practical compromise rather than a decision based on strict legal principles.

\section{Great Serbia as Alibi}

There follows the question of precisely what was the intention of Serbia's leadership when it presided over the mass killings in 1992, if it was not genocide. According to the judges:

The Applicant's [i.e. Bosnia's] argument does not come to terms with the fact that an essential motive of much of the Bosnian Serb leadership - to create a larger Serb State, by a war of conquest if necessary - did not necessarily require the destruction of the Bosnian Muslims and other communities, but their expulsion. ${ }^{38}$

This appears to be a case of honing the definition of genocide down so far that it disappears altogether. The same logic could be used to argue that even the Nazi Holocaust, or at least large parts of it, was not genocide. The equivalent would be,

... an essential motive of much of the Nazi leadership-to create a larger German State, by a war of conquest if necessary-did not necessarily require the destruction of the Jews and other communities, but their expulsion. 
Indeed, the Nazis initially tried to solve the Jewish problem, as they saw it, through forced emigration. The emigration of Jews from the Reich was not banned until October 1941, by which time the mass execution of Jewish men, women, and children was already well underway. The ICJ's logic would seem to imply that the Jews murdered by the Nazis, at least up until October 1941, were not genocide victims.

By acquitting Serbia of genocide on the grounds that its motive was merely to create an ethnically pure, enlarged state through mass killings and ethnic cleansing, the ICJ has made mass killings and ethnic cleansing into an alibi for those committing genocide. Indeed, by arguing that genocide ceases to be genocide when the killers have additional or higher motives for their killings, such as creating a larger state, the ICJ judges have opened up whole new vistas for the acquittal of states and individuals accused of genocide. If the creation of a larger state through killings and expulsions is not genocide, because the goal is the larger state rather than the killing as an end in itself, what then is genocide? Was the Nazi mass murder of Jewish hostages in reprisal for guerrilla actions in occupied Eastern Europe genocide? Was the working to death of Jewish slave laborers to produce armaments for the Wehrmacht genocide? Or the killing of Jews in Dr. Mengele's scientific experiments? After all, in all of these cases, the killings were for the purpose of goals that could technically have been achieved without them. If you want to be sufficiently pedantic, then you can make genocide disappear altogether. And this is effectively what the ICJ judges did.

Indeed, some of the judges themselves did not accept the acquittal. Two of the fifteen judges, including the ICJ's vice president, felt that Serbia was guilty of genocide. Four of the fifteen judges felt that Serbia was guilty of the lesser charge of complicity in genocide. In the words of Vice President al-Khasawneh:

The Court further notes that the motive of creating a Greater Serbia "did not necessarily require the destruction of the Bosnian Muslims and other communities, but their expulsion." The Court essentially ignores the facts and substitutes its own assessment of how the Bosnian Serbs could have hypothetically best achieved their macabre Strategic Goals... Coupled with population transfers, what other inference is there to draw from the overwhelming evidence of massive killings systematically targeting the Bosnian Muslims than genocidal intent? If the only objective was to move the Muslim population, and the Court is willing to assume that the Bosnian Serbs did only that which is strictly necessary in order to achieve this objective, then what to make of the mass murder? If the Court cannot ignore that population transfer was one way of achieving the Strategic Goals, then why should it ignore that, in fact, the Bosnian Serbs used this method as one of many-including massive killings of members of the protected group. ${ }^{39}$

Summing up, al-Khasawneh said,

The Court has absolved Serbia from responsibility for genocide in Bosnia and Herzegovina-save for responsibility for failure to prevent genocide in Srebrenica. It achieved this extraordinary result in the face of vast and compelling evidence to the contrary. ${ }^{40}$

I am not going to speculate on the motives of the judges. But it does appear that to acquit Serbia of genocide, while finding the Bosnian Serbs guilty of genocide at Srebrenica, is more in the nature of a compromise than a genuinely principled verdict. 
This may reflect a structural flaw in the ICJ as an instrument of justice. If the judges that make up the panel in a particular case come from different nations, then there may be pressure on them to uphold their particular national viewpoint when they deal with a case. So a verdict will reflect, to some extent, a compromise between different national viewpoints rather than a genuinely objective legal decision. Thus, for example, in each of the nine decisions of the ICJ panel of judges in the case of Bosnia vs. Serbia, the ad hoc judges appointed by Bosnia and Serbia each voted in favor of their respective states in every instance, while the judge from Serbia's ally Russia voted in Serbia's favor seven times out of the nine. ${ }^{41}$ Five out of the fifteen judges believed that the ICJ did not even have any jurisdiction to try Serbia for genocide in the first place, an issue which makes the final verdict seem even more like a compromise representing the middle ground. ${ }^{42}$

\section{Do the People of the Former Yugoslavia Feel that Justice Has Been Served?}

For these reasons and others, there is a widespread perception among many experts and commentators on the former Yugoslavia and the international courts that justice has not been served. The next question is how the working of the international courts is perceived among the former Yugoslav peoples. The work of the ICTY has been justified by its supporters as a necessary part of the process of reconciliation among the nations of the former Yugoslavia. The argument is that it is necessary to show that particular individuals are responsible for the war crimes, and to punish them legally and publicly, in order to absolve the nations as a whole of blame. There is, however, no evidence that this strategy has produced the desired effect. According to a recent study conducted by an international team of scholars led by Vojin Dimitrijevic and Julie Mertus, "The hope that it [the ICTY] might promote reconciliation between the peoples of the region does not appear to have been realised." 43 The scholars reached this verdict on the basis of an extensive study of opinion polls carried out in the former Yugoslavia.

This conclusion appears valid. The reasons why ordinary people in Serbia, Croatia, Bosnia, and Kosovo tend to feel that justice has not been done are, on the one hand, a tendency to see the indictment of their own war criminals as evidence of bias against their own nations and, on the other hand, a disappointment in the failure of the Tribunal to indict or convict certain notorious individuals. Such a sense of injustice is, of course, encouraged by nationalists among the former Yugoslavs and often by the governments themselves. Thus, for example, the indictment of prominent Croats and Serbs by the Tribunal has widely been presented as evidence of anti-Croat or anti-Serb bias. Conversely, the sense of hostile bias has been strengthened by prominent acquittals. Among Serbs, the effective acquittal of the Bosnian Army commander in Srebrenica, Naser Orić, for crimes carried out against Serb civilians at Bratunac is frequently cited as evidence of the Tribunal's anti-Serb bias. ${ }^{44}$ Among Croats, the acquittal of one member of the Vukovar Three and the initial sentencing of a second member to only a short prison term are likewise widely viewed as evidence of anti-Croat bias, and have even provoked a complaint from the Croatian parliament itself. ${ }^{45}$ Finally, Muslims are widely dissatisfied by the failure to arrest Mladić. Their sense of injustice, of course, increased by the ICJ's acquittal of Serbia for genocide. But the ICJ's affirmation that genocide occurred at Srebrenica was immediately rejected by Bosnian Serb Prime Minister Milorad Dodik, who claimed that the Srebrenica massacre "was not a genocide, although it was a terrible 
crime." 46 In Serbia, the ICJ's ruling is widely viewed as a vindication of Serbia's role in the war. The fact that the ICJ presented Serbia as guilty of systematic massive killings of Bosnian Muslims has generally been overlooked.

This failure of the international courts to achieve general acceptance and legitimacy in the eyes of the former Yugoslav peoples is not entirely their fault. As far as the ICTY is concerned, for it to have overcome all accusations of bias it would have had to operate on a much larger scale, to have indicted and sentenced much larger numbers of war criminals, and to have countered the bad impression created by the failure to indict certain notorious individuals and by the failure to convict some of those who were indicted. More importantly, however, the actions of the international courts, and particularly of the ICTY, were unlikely to promote reconciliation given the low level of public consciousness among different parties about their own sides' responsibility for the bloodshed and the unwillingness of the governments to raise this consciousness, by making, for example, public statements of responsibility or campaigns in the media. For example, because of the widespread belief in Serbia that Serbs were the least guilty for the war and that the international community is biased against them, and with nationalist politicians such as former Prime Minister Vojislav Koštunica unwilling to challenge this perception, any indictment or conviction of Serbs for war crimes is readily perceived as evidence of this alleged anti-Serb bias. The irony is that, as shown here, Serbia and Serb war criminals have been treated extremely leniently. Yet the ICTY is nevertheless widely perceived as anti-Serb by the Serbian public.

\section{Liberating Bosnia of War Criminals}

There are some partial qualifications that can be made to this largely negative evaluation of the record of the international courts. Firstly, the ICTY has at least succeeded in ridding Bosnia of some of the worst war criminals, who might otherwise have seriously obstructed the reform and reconstruction of the country that has occurred since Dayton. In this respect, it does not matter so much that Mladic has not been arrested or that Karadžić evaded arrest for thirteen years because they were at least driven underground and removed from the political scene. Among the Bosnian Croats, for example, Mladen Naletilić and Ivica Rajic have been convicted and sentenced. Had this not occurred, these two former warlords would in all likelihood have become criminal chiefs in post-war Bosnia, and would have terrorized local Muslims and moderate Croat politicians and corrupted or intimidated state officials. The fact that a vastly disproportionate number of Bosnian Serbs and Bosnian Croats have been indicted-as opposed to Serbs from Serbia and Croats from Croatia-has worked to the advantage of democracy and reform in Bosnia. Even simply removing those with blood on their hands from power counts for something. Nevertheless, if today's Bosnian political leaders are less murderous and overtly criminal, this does not mean that they are less nationalistic or more favorable to the spirit of reconciliation. The repeated threats by the current Bosnian Serb president and former prime minister, Milorad Dodik, to secede from Bosnia; his attendance at the nationalist anti-Western rally in Belgrade on 21 February 2008; his extension of a warm welcome to Bosnian Serb convicted war criminal Biljana Plavšić following her early release from prison in October 2009; and his claim that the Srebrenica massacre was not genocide and involved only 3,500 Muslim victims ${ }^{47}$ are evidence of this.

The second partial achievement of the ICTY is that forced the more moderate elements in Serbian and Croatian politics to confront the hard-line nationalists 
and to challenge the nationalist taboos. This has undoubtedly catalyzed the development of a more healthy pluralism and post-nationalist governing ethos in Croatia, although less so in Serbia. Overall, therefore, the international courts have made a positive contribution to regional progress. But if one ignores pragmatic political factors and evaluates the international courts simply by the extent to which they have delivered justice, then they must be judged to have greatly underachieved.

\section{Notes}

1. Jorgić v. Germany, European Court of Human Rights, fifth section, application no. 74613/ 01 (12 July 2007), 29.

2. Bosnia and Herzegovina v. Serbia and Montenegro: Case Concerning the Application of the Convention on the Prevention and Punishment of the Crime of Genocide, Judgement (26 February 2007), International Court of Justice, http://www.icj-cij.org/docket/files/91/ 13685.pdf (accessed 24 January 2011), 87-134.

3. Prosecutor v. Momčilo Krajišnik, Judgement (27 September 2006), International Criminal Tribunal for the Former Yugoslavia, http://www.icty.org/x/cases/krajisnik/tjug/en/krajud060927e.pdf (accessed 3 December 2010) 392.

4. Bogdan Ivanišević, The War Crimes Chamber in Bosnia and Herzegovina: From Hybrid to Domestic Court (New York: International Center for Transitional Justice, 2008).

5. Examples of works in this genre are Susan Woodward, Balkan Tragedy: Chaos and Dissolution after the Cold War (Washington, DC: The Brookings Institute, 1994); Diana Johnstone, Fools' Crusade: Yugoslavia, NATO and Western Delusions (London: Pluto Press, 2002); Michael Parenti, To Kill a Nation: The Attack on Yugoslavia (London: Verso, 2001); Kate Hudson, Breaking the South Slav Dream: The Rise and Fall of Yugoslavia (London: Pluto Press, 2003).

6. Thomas Fleming, "The Crime of the Serbs: US Foreign Policy in the Balkan War," (speech, Symposium on the Balkan War, Chicago, 1 September 1995), http://www.srpska-mreza.com/nwo/TFleming-95.html (accessed 5 April 2008).

7. On the Islamist perception that the Western powers were behind the Serb campaign in Bosnia, see, for example, Evan F. Kohlmann, Al Qaida's Jihad in Europe: The AfghanBosnian Network (Oxford: Berg, 2004), 73.

8. Brendan Simms, Unfinest Hour: Britain and the Destruction of Bosnia (London: Allen Lane, 2001).

9. Florence Hartmann, Paix et châtiment: Les guerres secrètes de la politique et de la justice internationales, (Paris: Flammarion, 2007).

10. Johnstone, Fools' Crusade, 91-109, 118-123; Parenti, To Kill a Nation, 127-28; Hudson, Breaking the South Slav Dream, 162-64. These unserious books are not, it should be made clear, on par with Hartmann's important and well-informed, if sometimes problematic, book.

11. Hartmann, Paix et châtiment, 165-246.

12. Cees Banning and Petra de Koning, "Karadžić Still Free because of Politics," NRCHandelsblad, 20 June 2004, trans. International Justice Watch (4 April 2005), http://listserv.buffalo.edu/cgi-bin/wa?A2ind0504\&L=JUSTWATCH-L\&P=R7141 (accessed 9 April 2008).

13. Prosecutor v. Radovan Karadžić: Decision on the Accused's Holbrooke Agreement Motion, Judgment (8 July 2009), International Criminal Tribunal for the Former Yugoslavia, http://www.icty.org/x/cases/karadzic/tdec/en/090708.pdf (accessed 20 July 2009).

14. Nidžara Ahmetašević, "Pentagon behind Karažić Immunity Deal," BalkanInsight, 6 August 2008, http://old.balkaninsight.com/en/main/investigations/12277/?tpl=297 (accessed 20 July 2009); Matjaž Klemenčić, "The International Community and the FRY/ Belligerents, 1989-1997," in Confronting the Yugoslav Controversies: A Scholars' Initiative, ed. Charles Ingrao and Thomas A. Emmert (West Lafayette, IN: Purdue University Press, 2009), 187. 
15. Carla del Ponte and Chuck Sudetic, Madame Prosecutor: Confrontations with Humanity's Worst Criminals and the Culture of Impunity (New York: Other Press, 2008).

16. Victor Peskin, International Justice in Rwanda and the Balkans: Virtual Trials and the Struggle for State Cooperation (Cambridge, UK: Cambridge University Press, 2008).

17. Author's calculation based on examination of the indictments on the ICTY website, www.icty.org/action/cases/4, 10 April 2008.

18. Author's calculation based on data presented in the study conducted by Mirsad Tokača's Research and Documentation Centre, Sarajevo, "Human Losses in Bosnia-Hercegovina, 1991-1995: Research Results and Project Evaluation," http://www.idc.org.ba/. See also Marko Attila Hoare, What Do the Figures for the Bosnian War-Dead Tell Us?, Greater Surbiton blog, 4 January 2008, http://greatersurbiton.wordpress.com/2008/01/04/whatdo-the-figures-for-the-bosnian-war-dead-tell-us/ (accessed 10 April 2008).

19. Dražen Živić and Nenad Pokos, Demografski gubitci tijekom Domovinskog rata kao odrednica depopulacije Hrvatske (1991-2000) [Demographic losses during the Patriotic War as a determinant of the depopulation of Croatia (1991-2000)] (Zagreb: Institut društvenih znanosti Ivo Pilar, 2004), 737-38.

20. Patrick Ball et al., Killings and Refugee Flow in Kosovo, March-June 1999: A Report to the International Criminal Tribunal for the Former Yugoslavia (New York: American Association for the Advancement of Science, 2002), 5-6; Paul B. Spiegel and Peter Salama, "War and Mortality in Kosovo, 1998-99: An Epidemiological Testimony," The Lancet 355, no. 9222 (June 2000): 2204-9.

21. Hartmann, Paix et châtiment, 81-82.

22. Florence Hartmann to Marko Attila Hoare, e-mail, 13 January 2008, in the author's possession.

23. See Norman Cigar and Paul Williams, Indictment in the Hague: The Milošević Regime and the Crimes of the Balkan Wars (New York: New York University Press, 2002); Marko Attila Hoare, How Bosnia Armed (London: Saqi Books, 2004), 31-42, 70-71; Hannes Tretter et al., Ethnic-Cleansing Operations in the Northeast Bosnian city of Zvornik from April through June 1992, report (Vienna: Ludwig Bolzmann Institute of Human Rights 1994; 1998).

24. Prosecutor of the Tribunal v. Slobodan Milošević, Amended Indictment (21 April 2004), International Criminal Tribunal for the Former Yugoslavia, http://www.icty.org/x/cases/ slobodan_milosevic/ind/en/mil-ai040421-e.htm (accessed 24 January 2011).

25. Ibid.

26. Florence Hartmann to Marko Attila Hoare, e-mail, 12 January 2008, in the author's possession.

27. Merdijana Sadović, "Nice Assesses ICTY Prosecution Record," Institute for War and Peace Reporting, 24 January 2008, http://iwpr.net/report-news/nice-assesses-ictyprosecution-record (accessed 24 January 2011).

28. Gideon Boas, The Milošević Trial: Lessons for the Conduct of Complex International Criminal Proceedings (Cambridge, UK: Cambridge University Press, 2007), 1, 112.

29. Ibid., 115-30.

30. "Convention on the Prevention and Punishment of the Crime of Genocide," Office of the United Nations High Commissioner for Human Rights, accessed 24 January 2011, http://www2.ohchr.org/english/law/genocide.htm.

31. Mark Levene, Genocide in the Age of the Nation State: The Meaning of Genocide, vol. 1, (London, I. B. Tauris, 2005), 45.

32. Slobodan Kostić, "How Belgrade Escaped Genocide Charge," Institute for War and Peace Reporting, 2 May 2008, http://iwpr.net/report-news/how-belgrade-escaped-genocidecharge (accessed 24 January 2011).

33. Marlise Simons, "Serbia's Darkest Pages Hidden from Genocide Court," International Herald Tribune, 8 April 2007.

34. See Ruth Wedgwood, "Bad Day for International Justice," International Herald Tribune, 8 March 2007. 
35. Bosnia and Herzegovina v. Serbia and Montenegro.

36. See, for example, David Rohde, Endgame: The Betrayal and Fall of Srebrenica, Europe's Worst Massacre since World War II (New York: Farrar, Strauss and Giroux, 1997), 16780; Jan Willem Honig and Norbert Both, Srebrenica: Record of a War Crime (London: Penguin, 1996), 28-45.

37. Ibid., $157-58$.

38. Ibid., 133.

39. Ibid., "Appendix: Dissenting Opinion of Vice-President Al-Khasawneh," 11-12.

40. Ibid., 17.

41. Ibid., 168-70.

42. See Wedgwood, "Bad Day for International Justice."

43. Vojin Dimitrijević, Julie Mertus, et al., "The Hague Tribunal (ICTY)," Scholars' Initiative, accessed 10 April 2008, http://www.salzburgseminar.org/ihjr/si/si/Team_10_Full_ Text_Report.pdf, 86.

44. For example, see "No Justice for Serbs," De[construct], 3 July 2006, http://de-construct. net/?p=151, (accessed 10 April 2006); "Hague Tribunal Confirms its Anti-Serb Bias," Serbo Journal blog, 30 September 2006, http://serbo.blogspot.com/2006/09/hague-tribunalconfirms-its-anti-serb.html (accessed 10 April 2006).

45. Goran Jungvirth, "Vukovar Judgement Slammed," Balkan Investigative Reporting Network, 4 October 2007.

46. Dejan Anastasijeivjć, "Defining Genocide down in Bosnia," Time, 27 February 2007.

47. "Srebrenica Was Not Genocide: Bosnian Serb Leader," France 24 International News 24 / 7, 27 April 2010, http://www.france24.com/en/20100427-srebrenica-was-notgenocide-bosnian-serb-leader (accessed 3 December 2010). 


\section{Notice of Errata}

The article by Marko Attila Hoare, "A Case Study in Underachievement: The International Courts and Genocide in Bosnia-Herzegovina," GSP 6, 1 (April 2011): 81-97, was published with the following errors:

On p. 81, for "Only one middle-ranking individual has been convicted of a genociderelated charge by the ICTY" read "Only one middle-ranking individual has been definitely convicted of a genocide-related charge by the ICTY"; for "So far, the ICTY has successfully prosecuted one individual for genocide" read "So far, the ICTY has definitely successfully prosecuted one individual for genocide".

On p. 83, for "Only one individual-a lowly deputy corps commander-has been convicted of a genocide-related charge by an international court" read "Only one individual-a lowly deputy corps commander-has definitely been convicted of a genocide-related charge by a fully international court".

On p. 93, for "Among Croats, the acquittal of one member of the Vukovar Three and the initial sentencing of a second member to only a short prison term are likewise widely viewed as evidence of anti-Croat bias, and have even provoked a complaint from the Croatian parliament itself" read "Among Croats, the acquittal of one member of the Vukovar Three and the initial sentencing of a second member to only a short prison term were likewise widely viewed as evidence of anti-Croat bias, and even provoked a complaint from the Croatian parliament itself".

An updated version of the article containing these corrections is now available at GSP Online (doi:10.3138/gsp.6.1.81). GSP and our publisher regret these errors, which are the sole responsibility of the publisher. 